\title{
Business Model Management Typologies-Cognitive Mapping of Business Model Landscapes
}

\author{
Diana Chroneer ${ }^{1}$, Jeaneth Johansson ${ }^{1} \&$ Malin Malmstrom ${ }^{1}$ \\ ${ }^{1}$ Lulea University of Technology, Sweden \\ Correspondence: Diana Chroneer, Lulea University of Technology, Sweden. E-mail: diana.chroneer@ltu.se
}

Received: September 16, 2014

Accepted: January 27, 2015

Online Published: February 27, 2015

doi:10.5539/ijbm.v10n3p67

URL: http://dx.doi.org/10.5539/ijbm.v10n3p67

\begin{abstract}
Business model management is critical in the development of business models aimed to launch innovations and generate high venture performance. This study presents the use of personal construct theory and the repertory grid methodology, a new technique to explore central factors in entrepreneurs' business model management. We identify typologies for business model management and underlying logics of these typologies.

The study advances the business model literature in several ways. First it contributes with visualisation of entrepreneurs' business model management and hence adds dimension of business model management. Second, theories and methods from cognitive psychology contribute to the literature with new knowledge on business model management. Repertory grid methodology, developed from Personal construct theory, enable identification of entrepreneurial cognitions of business models.

Through 11 semi-structured interviews with serial entrepreneurs in the mobile service sector, this paper contributes with a framework that advances the business model literature by identifying business model management strategies and its defining features. Three categories are identified including six types of business model management strategies for navigating management of business models. The identified categories are: 1) "Comprehensive management" characterized by various levels of complexity, uncertainty, and variation, 2) "Risk management" characterized by various types of risks e.g. business, financial and social, and 3) "Resource management" characterized of various types of capital; e.g. financial, social, human, and innovation. The business model management typologies may assist entrepreneurs to reflect on their business model design and management. This study suggests that the repertory grid technique may be useful in understanding business model management.
\end{abstract}

Keywords: business model, business model development, cognitive mapping

\section{Introduction}

What enables some innovative ventures to survive and become successful while others do not? Indeed, the venture's business model is critical for the venture's enactment. Business models have been a defining feature in innovation and its management, which is widely considered as the basis of a competitive economy (Xavier, 2010; Lindgren, 2012). However, business models as such are not enough; ventures also need to manage the business models to become competitive. Competitive success is seen as dependent upon an organization's management of the innovation process and proposes factors that relate to successful management of the innovation process (Balachandra \& Friar, 1997; Di Benedetto, 1996). Yet the phenomenon of business models in innovative management is relatively unexplored in research. Worldwide, business models are important for innovation. Without a well-developed business model, innovators will fail to either deliver or to capture value from their innovations. This is especially true for, business models in in many sectors undergoing transition due to higher degree of customer focus in the business models. Therefore, businesses need to re-evaluate the value propositions in the business models presented to customers (Teece, 2010).

The innovation context in which ICT-ventures operate suggests that business models are a problematic and challenging topic. When business models are successful, that is, it helps develop successful ventures, society as a whole benefits and new technologies and innovations emerge. Business models can be seen as a system of interdependent activities that transcends the focal firm and spans its boundaries (Zott \& Amit, 2010). Also, business models are powerful for supporting management in the analysing, implementing, and communicating 
strategic choices for creating and capturing business potentials of performance, growth, and survival, it is essential to increase the understanding of strategies of business model management and hence how to manage innovation. Thus, a firm's business model serves two interlinked purposes: to provide some stability for the development of a venture's activities and, at the same time, to be flexible enough to allow for change (Cavalcante et al., 2011).

Despite the significance of business models, ventures face significant challenges in their innovation management The business model literature has tried to find overarching business model logics (e.g. Osterwalder et al., 2005). However, companies are heterogeneous in nature which is why there is a need for business model logics to be adjustable to the specific company in order to support its business venturing for achieving high performance. Adjustability is especially critical in dynamic industries such as in the mobile service industry, which is a relatively young and rapidly evolving sector (Ballon, 2007). Innovative SMEs operating in such dynamic environment face a continuous need to adjust their business models and are therefore in constant need of business model development for capturing new opportunities (Wiklund \& Shepherd, 2003). In addition, the business model literature typically lacks empirical testing (Chesbrough \& Appleyard, 2007; Chesbrough \& Schwartz, 2007). A vast body of literature has examined business modelling focusing on for instance definitions, components and how components interrelate with each other in order to capture and create value (Morris et al., 2005; Osterwalder et al., 2005; Shafera et al., 2005; Cavalcante et al., 2011). But one prominent gap in the field is that lack of empirically anchored strategies for managing business models (von Hippel, 2001).

In this search for business potential the ability of entrepreneurs to design and organize appropriate business models are critical (Shafera et al., 2005). Entrepreneurs who have a rich understanding of organizational capabilities and the dynamics of industry structures have been found to be able to improve company performance (Gary \& Wood, 2011). Yet, business models are seldom formally expressed by the entrepreneurs and exist as subconscious knowledge (Morris et al., 2005). As a consequence, entrepreneurs have difficulties in extracting their knowledge to act and react on need for adjustments in the business model. Without explicit access to the knowledge of the business model, management of the same may become as the old saying suggests; "Blind squirrels do occasionally find acorns, but, until they do, there is a lot of wasted effort." Just like squirrels, entrepreneurs spend time and effort and may run out of fuel before reaching their target such as performance.

In is shown that entrepreneurs' knowledge structures of the company's business model may be captured through the entrepreneurs' cognitive thought structures (Gary \& Wood, 2011), which is what this study attempts to accomplish. Thereby, this study contributes with knowledge on business model management strategies through the development of typologies based on underlying logics of central factors in the mobile service industry. Specifically, different typologies of strategies are described each highlighting its specific factors of importance.

\section{Brief Review of the Business Model Literature}

In pursuit of answers to the central question of business models, management scholars have investigated the concept Business Model (BM), a concept that has flourished extensively in the managerial literature since the end of the 90s (Osterwalder \& Pigneur, 2004; Chesbrough, 2010). Research on business models has obtained a great deal of interest the last decade and a review of the literature reveals three main phases in the progress of this research. The first phase typically focuses on business model definitions (cf. Amit \& Zott, 2001), the second on business model content such as components and atomic elements (cf. Petrovic et al., 2001) and the third phase emphasizes business model as an integrated framework (cf. Morris et al., 2005; Osterwalder et al., 2005; Shafer et al., 2005).

There is a substantial base of studies defining the concept of business model (Amit \& Zott, 2001; Pateli \& Giaglis, 2003) and there appear to be a consensus among researchers regarding the fundamentals of a business model such as target market, value proposition, resources, key activities, cost and revenue model, value chain. (e.g. Morris et al., 2005; Chesbrough, 2007; Johansson \& Malmström, 2013; Malmström, 2014). It is here interesting to note that some researchers incorporate strategy into business models while other view strategy as an overarching level and not part of the business model per se (Chesbrough \& Rosenbloom, 2002; Chesbrough, 2007). Research also shows that the business model field has now matured to a degree that allows it to move beyond the elementary definitional studies, associated with the definitions and components sub domains, to more in-depth analyses aiming to provide integrated frameworks for representing, analysing assessing and changing business models (Pateli \& Giaglis, 2003).

Further, the business model literature often link business models either to an economic perspective and/or organizational perspective. The economic perspective concerns the logic of profit generation and deals with cost structures and revenue streams (Stewart \& Zhao, 2000; Malmström et al., 2014) while the organizational 
perspective focuses on how firms are organized in order to discover and exploit opportunities to create value in the marketplace (Osterwalder \& Pigneur, 2004; Malmström et al., 2013; Malmström \& Wincent, 2012). The literature also relates business models to both business processes (Morris et al., 2005) and strategy (Pateli \& Giaglis, 2004). Business processes relates to all those processes involved in a firm's value capturing and value creation while the strategic perspective define a business model as "a representation of a firm's underlying core logic and strategic choices for creating and capturing value within a value network." (Shafer et al., 2005, p. 202).

In the literature, business modelling are approached either as static blueprints of core business model components or as dynamic processes addressing change and innovation in the organization that create and capture values through identification of potentials or threats (Demil \& Lecocq, 2010; Johansson et al., (2012). However, there is a lack of research focusing how such relations may be dealt with. Current research indicates that rather than being recognized as a static and simple concept, focusing on a single firm, a business model of today is generally seen as a dynamic and complex process (Ballon, 2007). Nevertheless, studies indicate that companies hardly show flexibility in choosing appropriate business models (Van der Meer, 2007). Chung et al. (2004) emphasize that the success of business models depends on the ability to adjust the business model in accordance to critical contextual factors. It is also identified in the literature that business models need to be developed in accordance with contextual factors and thus business processes and strategies must be linked to the business model development (Smith et al., 2008). Therefore, we believe that there are several reasons to expect heterogeneity in business model management strategies that produces high performance. We also posit that business models consist of many components where the components' content and interrelations are dynamic and need to be managed and adjusted continuously. Business model management involves choices made by entrepreneurs about how to operate the company and also consequences of these choices (Casadesus-Masanell \& Ricart, 2010).

\section{The Research Design and Setup}

The study presented in this paper focus on serial entrepreneurs in the Information and Communication Technology sector (ICT). We define serial entrepreneurs as those who have had a minority or majority ownership in one or more independent businesses which they have sold or closed (cf. Westhead et al., 2005). In addition, they currently have a minority or majority ownership stake in one or more independent businesses. The serial entrepreneurs chosen and interviewed in this study were identified by using a Swedish archival venture database (Affärsdata) in which the entrepreneur's history of venturing is registered. In this database, we selected a sample of serial entrepreneurs with a history of business models related to software, electronics, computer equipment, and telecommunications in the ICT sector (Audretsch et al., 2008; Baum et al., 2011). The ICT sector is characterized by a high intensity in both technology and knowledge (e.g., Tidd \& Trewhella, 1997), which may indicate that certain business model factors could be unique to this specific setting. The decision to choose entrepreneurs in the ICT sector was to reduce the industry effects and thus achieve a higher possibility of detecting patterns that otherwise would be more difficult to recognize (Baum et al., 2011). The research design aimed to test and apply the repertory grid instrument for exploring the interrelationship between the central factors for business model management strategies. This step included interviews with 11 entrepreneurs with experiences from a total number of 69 business models. All the entrepreneurs (respondents) had an extensive experience in both starting and running ventures, also including developing and managing business models in practice. The first eleven serial entrepreneurs who matched the criteria were contacted and all agreed to participate. The sample size consisting of 11 respondents is according to the recommendation of the needed number of respondents to identify cognitive constructions (cf. Guest et al., 2006; Kwong et al., 2012). In the sample, a typical serial entrepreneur had about 50 years of age, had 20-30 years of entrepreneurial experience, had started 5-6 ventures, and they all had a university education in engineering. In total, 69 business models were discussed, which are a sufficient number of data needed for grid analysis (Jankowicz, 2004). The entrepreneurs in the main study had the possibility to add constructs and one additional constructs were based on this included in the very first interview, resulting in a total number of 27 constructs used in the study, e.g. Technology complexity, Uncertainty in Product technology, Market dynamics (see Appendix 1 for all the constructs). The total amount of the interviews with the entrepreneurs summed up to additionally approximate 40 hours.

\subsection{Application of the Repertory Grid Methodology}

The theoretical background for understanding entrepreneur's business modeling that forms the basis of the reasoning in this paper is tied to research by Kelly (1955), who developed the repertory grid methodology and the attached Personal Construct Theory (PCT). The methodology and the theory allows for visualisation of the entrepreneurs' social constructions of their business modeling, i.e. constructions that in many cases are sub-conscious "in the head of the entrepreneur". The entrepreneurs, seeks according to the personal construct 
theory to understand the central factors for business model management strategies and also to predict and control for the future through forming of "theories" or "hypotheses" of what business model management mean to them. This view acknowledges social construction by which the entrepreneurs make sense of and navigate their social worlds of business model management. The in the business and management literature frequently used methodology (Hisrich \& Jankowicz, 1990; Senior, 1997) enables operationalization of the personal construct theory. More specifically the entrepreneurs visualize their thought structures of business model management strategies through conceptualisations of what they consider to be central factors for management (Fransella et al., 2004). For example, the technique can reveal what centrality entrepreneurs pose on different factors in their management of business models and through this visualize more or less subconscious thought structures (Fransella et al., 2004). In fact, the methodology has potential to reveal what experts may be unable to articulate since it enables more or less subconscious structures to become conscious and aware (Diáz de Leon \& Guild, 2003).

Entrepreneurs' conceptualization is based on the entrepreneurs comparing of different business model experiences (Jankowicz, 2004) in terms of what business models are, and consequently, what they are not. In this, they use and contrast central factors for understanding the business models. A contrasting central factor extends between two reference points, such as between "low" and "high." For example, for an entrepreneur to make sense of a venture's market maturity, the entrepreneur categorizes, generalizes, and tests the relative market maturity of the particular business model with experiences from the other business models. Some business models are connected to low market maturity while other are connected to high market maturity. In order to determine if a business model has a "high" or "low" degree of external financing, the entrepreneur compares this measure with the other business models that he/she has experience of. So by contrasting the central factors, which is fundamental in the repertory grid technique (Fransella et al., 2004), the rating provides an outline of entrepreneurs' thought structures.

Since serial entrepreneurs generally can be denoted as possessing expert knowledge (Diáz de Leon \& Guild, 2003), they are suitable candidates in studies using the repertory grid technique (Hart, 1986). Expert knowledge can consist of venturing or industry experience (Baum et al., 2011). Therefore, analyzing the serial entrepreneurs' cognitive constructions can grasp a colorful and relevant image of socially constructed knowledge about fundamental business modeling factors (Dunn \& Ginsberg, 1986). Thus, gaining an access to comprehensive cognitive constructions gives us a model of entrepreneurs' business modeling.

Using the repertory grid technique in business model research has several advantages. Firstly, this technique allows researchers to grasp the entrepreneur's own understanding of business modeling, that is less conscious, rather than the researcher suggesting a specific meaning and content (Ginsberg, 1989). Gaining knowledge and understanding of the entrepreneurs' thought structures may support entrepreneurs' conscious business modeling decisions (Johansson \& Malmström, 2014). Thus, more underlying questions can be explored that reveal for instance less conscious aspects of business modeling that an entrepreneur should learn how to manage, and how an entrepreneur can use the awareness of central factors for business modeling for achieving more effective venturing (Johansson, 2004). Secondly, a specific interview style developed to capture influential cognitive factors for business modeling is of importance in the repertory grid technique. Therefore, the technique provides data that can be analyzed through validated methods to understand underlying and actual changes of comprehensive cognitive constructions (Dunn \& Ginsberg, 1986). Researchers can also learn more about changes in cognitive constructions and whether cognitive constructions, in this case, of prior business modeling influence subsequent business models. Thirdly, we argue that the imbedded inductive and analytical approach in the repertory grid technique outlines a repertoire of developing working hypotheses based on how entrepreneurs cognitively construct business models. That is, portraying how entrepreneurs understand their business models and how they comprehend causes and effects of committed courses of action. In this study, individual entrepreneurs first constructed a tentative course of action and then had the possibility to revise their approach when exposed to mismatches. In uncertain venture environments, this enabled us to comprehend trial-and-error learning and to identify early signs of how complex, inimitable, and rare business models are developed (cf. Mosakowski, 1997).

The repertory grid interview protocol used in this study (see Appendix 1) was in line with common research practice consisting of five steps and inductively generated (Diáz de Leon \& Guild, 2003). First, the interviews with the entrepreneurs focused on capturing their specific stories of self-experienced business modeling. Second, we coded the stories and identified preliminary central factors. Third, additional central factors were identified using the triadic technique. In this step, the entrepreneurs compared three of their self-experienced business models to identify central factors (Ginsberg, 1989). The entrepreneurs were asked following question "In what 
way are two of these business models similar to one another and different from the third?" (Shaw \& Woodward, 1990). Then in step four, the entrepreneurs discussed and validated the inductively identified central business model factors that were revealed in steps 1 through 3 . Also, the entrepreneurs were given the opportunity to add additional central factors, but all entrepreneurs were satisfied with the existing factors, implying that a saturation level was reached. This addresses the study's reliability (Fransella et al., 2004). Fifth, the identified central business model factors were verified with the existing business model literature (cf. Chesbrough \& Rosenbloom, 2002). Altogether, a total sum of 27 contrasting central business model factors was identified.

In sum, the five steps described above ensure identification of relevant central business model factors with an appropriate detailed level for inclusion in the repertory grid interview protocol. As such, the five steps enabled us to validate the central business model factors (Rayment, 2000; Fiske \& Taylor, 1984; Fransella et al., 2004) and to address both the reliability and validity of the interview protocol (Jankowicz, 2004).

The generated interview protocol was used for conducting repertory grid interviews. Each entrepreneur was asked to select four or more business models that they had developed and managed. The entrepreneurs hereafter thought aloud (discussed) about their selected business models that they had developed and pursued in practice. In this "thinking-process", they compared and scaled their chosen business models on the 27 contrasting central business model factors in the repertory grid interview protocol. This comparison and rating consisted of using a 7-point Likert scale on each of the 27 central business model factors. For example, the entrepreneurs rated 'the uncertainty in product technology' of the selected business models on a scale anchored by $1=$ low product complexity to $7=$ high product complexity (Pope \& Keen, 1981; Ginsberg, 1989; Yeung \& Watkins, 2000; Fransella et al., 2004; Jankowicz, 2004). Figure 1 illustrates an example of a fictitious entrepreneur's repertory grid protocol based on seven fictitious business models and eight central business model factors. The example portrays, for example, that Business Model 7, with the rating of 1, has the lowest product complexity, whereas Business Model 2, with the rating of 7 has the highest product complexity (rating according to Pope \& Keen, 1981). The serial entrepreneurs rated all the 27 central business model factors to their individually chosen business models. In total, the interview time added up to 20 hours. To ensure reliability, all interviews were recorded and transcribed (Eisenhardt, 1989). Moreover, the entrepreneurs were promised anonymity, which likely improved access to truthful cognitive structures. For a manual of administering and scoring repertory grid interview protocols, see Fransella et al. (2004).
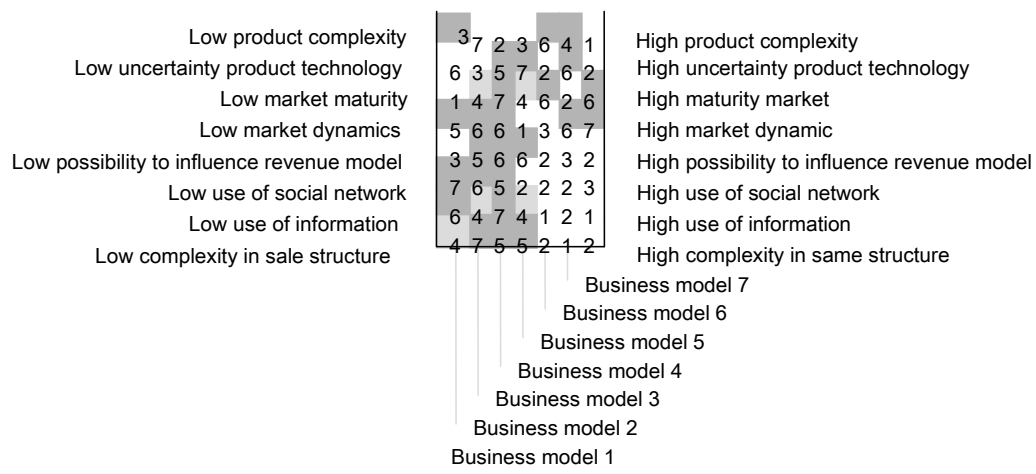

Figure 1. Illustrative example of a repertory grid and its ratings

\subsection{Analyzing the Repertory Grids}

The main objective of analysing the study' repertory grid interview protocols was to explore the cognitive constructions of business model management strategies among a group of serial entrepreneurs. Initially, we analysed the descriptive statistics of the central business model factors for 69 business models. Second, we analysed the serial entrepreneurs' cognitions using the software REPGRID (Ver. 2.1) (Gaines \& Shaw, 1990), with hierarchical and spatial cluster analyses, FOCUS (Shaw, 1980; Brown, 1992) and principal components analyses (PCA) (Slater, 1976; 1977). In accordance with the personal construct theory, we identified entrepreneurs' cognitive constructions of their business models (Bannister \& Fransella, 2003; Fransella et al., 2004). The findings on group-level analyses of business model management strategies were checked against individual levels. These checks indicated stability in the findings in line with the reliability check (Fransella et al., 
2004; Jankowicz, 2004). In this study, the calculations were performed with the software REPGRID, version 2.1 (Gaines \& Shaw, 1990b). The software graphically maps both the business models and the central business model factors in a two-dimensional space in which the two orthogonal axes represent the principal components. The loadings of the business models and their central business model factors on the principal components are responsible for the pattern correlation on the map; that is, the higher the loading, the greater the significance of certain business model factors to characterize a business model on a principal component. The cognitive map shows the entrepreneurs social constructions of business models and indicates how the central factors group together and explain logics behind different business models (i.e. characterize a specific business model management strategies). An illustrating example of the geographical representation of central business model factors and the most central components are presented below for capturing the fundamental idea of personal construct theory and the repertory grid technique.

An illustrative example of business models and central business model factors are in Figure 2 plotted within the four quadrants and defined by two axes, "Components", in accordance with their coordinates, i.e. "Loadings" (Pope \& Keen, 1981). In this study, component 1 explains in the example $39.2 \%$ of the variance in the material and component $220.5 \%$. The first component is foremost explained by four central business model factors (use social network, complexity in sale structure, use information, possibility to influence revenue model) and the second component by two central business model factors (market dynamics, product complexity). Each one of the business models B1-B7 are also positioned on the graphical illustration. The next step in the repertory grid analyses is to interpret the principal components. Each one of the components and the poles and contrasts (poles and contrasts have opposite characteristics, e.g. high vs. low market dynamics) are labelled based on the content.

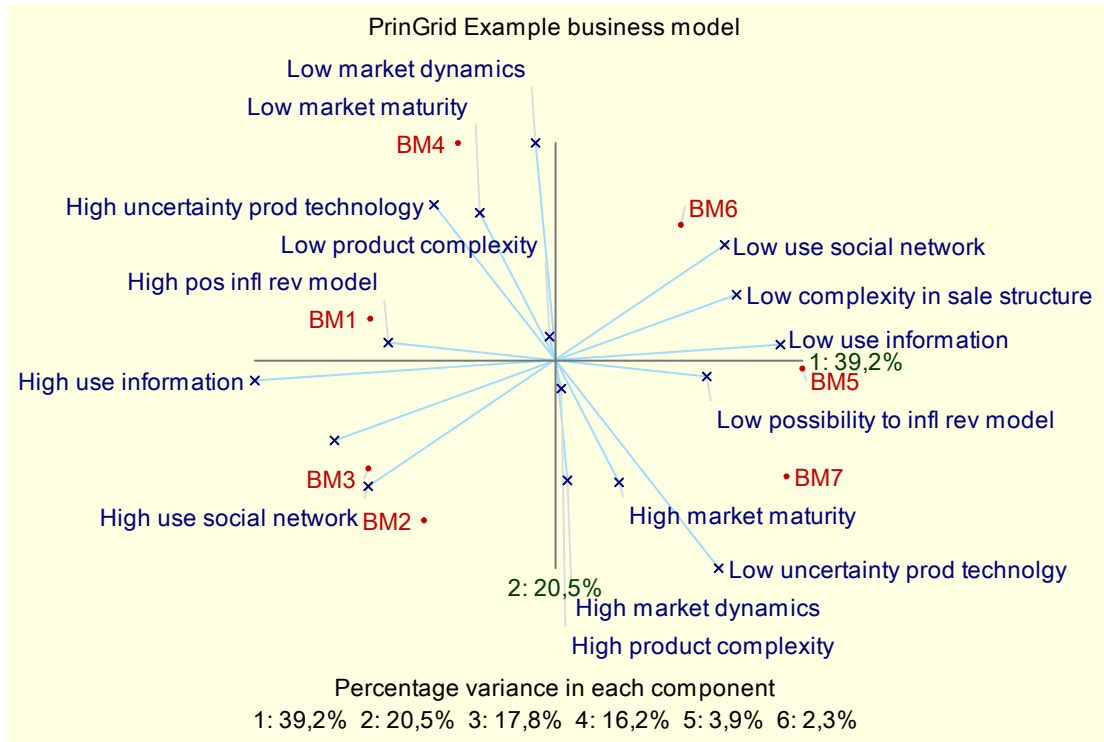

Figure 2. Example of the principal components and the positions of business models in the quadrants

\section{Empirical Findings}

This paper set out to explore central factors in entrepreneurs' business model management strategies by identifying typologies of business model management and their underlying logics. The PCA indicated a complex pattern of business model factors in the mobile service sector. No less than 18 components were needed for explaining the whole model on the factors behind the business model management. However, in this study it was suitable to look into three of these 18 components since each one of these explained close to ten or more percentage of the variance, which is a guiding rule, see Table 1.

Table 1. Percentage of variance for each component

\begin{tabular}{llll}
\hline & Component 1 & Component 2 & Component 3 \\
\hline Variance \% & 16,55 & 13,43 & 9,51 \\
Accumulated variance \% & 16,55 & 29,98 & 39,49 \\
\hline
\end{tabular}

The three components, and their attached pole and contrasts, are further explained in the following sections. The 
components were defined by the most significant constructs, i.e. those with loadings 1.5 and above. Three main business model management typologies were identified. Since each management typology relates to a Pole and Contrast, a total number of six typologies explains the dynamic processes in business model management on the polar ends of three dimensions (and type of strategy);

1) Comprehensive business model management (Polar ends: Demanding vs. Simple);

2) Risk management business model (Polar ends: High risk vs. Low risk;

3) Resource acquisition business management (Polar ends: Extended vs. Limited).

Three core groups of business model factors were identified which outline mechanisms for business model management logics through inductive interpretation of the six management typologies and their attached business model factors (constructs);

1) Key structural characteristics,

2) Key dominate governance scheme,

3) Key operational orchestration/activities.

The Key structural characteristics refer to the central contextual parameters of the business model factors outlining the stock/status of the company. The Key dominate governance scheme refers to the way the entrepreneurs approach the Key structural characteristics of the business model factors. This is outlined in organizational structure and business model design in terms of flexibility and stability. The Key operational orchestration/activities refer to central activities related for executing the governance scheme for acting in accordance with conditions outlined by the Key structural characteristics. The three groups of business model factors altogether outline six business model management typologies.

The first management dimension, "Comprehensive business model management" was in the analysis characterised by 14 significant business model factors. In this management dimension, the Pole refers to the first typology of the business model management, i.e. the "Demanding business model management" while the Contrast refers to the second typology; the "Simple business model management", which have opposite characteristics of the Pole. Below are the Pole illustrated in more details as the Key structural characteristics of the "Demanding business model management" relates to both internal and external complexity, i.e. high complexity in technology, high complexity in sale structures and high degree of customer involvement. The key structural characteristics also refer to high market dynamics and hence high uncertainties and variations. The business model is also financially demanding, i.e. capital intensive and in need of external venture capital. The Key operational orchestration/activities are characterized by a high degree of information use and high complexity in the decision process. The Key dominate governance scheme refers to a business model organization demanding high degrees of structures (high stability) and a business model design requiring high degrees of flexibility, for instance possibilities to influence the revenue model.

The second management dimension, the "Risk management business model" was in the analysis characterized by 11 significant business model factors. In this management dimension, he Pole refers to the third typology of the business model management, i.e. the "Low risk business model management strategy" while the Contrast refers to the fourth typology; the "High risk business model management strategy". The Pole is illustrated below in more details. As the Key structural characteristics of the "Low risk business model management" relates to low business risk, implying for instance low product complexity and a low degree of technology focus in the business model. The Key structural characteristics also refer to low financial risks, for instance low capital intensity and a business model focusing on earnings today. Further, the business model is also characterized by high degrees of customer involvement and an extended use of social networks, which imply an external business model focus. The Key operational orchestration/activities for this business model management typology refer to high degree of information use. Finally, the Key dominate governance scheme refers to a business model organization demanding high degree of organizational structure (high stability) and a business model design requiring a low degree of stability (high flexibility).

The third management dimension, the "Resource acquisition business management" was in the analysis characterised by 10 significant business model factors. In this management dimension, focus tends to be on different types of resources and acquisition of resources. The Pole refers to the fifth management typology the "externally oriented resource business model management" and the Contrast refers to the sixth management typology the "internally oriented resource business model management". The Pole is illustrated in more details as the Key structural characteristics of the "Externally oriented resource acquisition business model management" relates to a business model in a dynamic high technology environment with a high market focus 
where resources in terms of human, social, and financial resources are central. The human resources include both a high degree of internal front edge competence and high use of external competence where the latter also represent the social resources. The social capital further refers to high use of external sales channels, high degree of customer involvement and high use of social networks. The financial resources are to a high degree based on internally generated financial means while the current earnings are limited and foremost expected in the future. In this business model, the Key operational orchestration/activities are related to extended use and acquisition of resources, i.e. human, social and financial resources. The Key dominate governance scheme refers to a business model organization and business model designs both outlining low stability and thus high flexibility by the high degree of customer involvement in the business model design and consequently have impact on the flexibility in the organizational design. The flexibility in organizational design is also a consequence of the external orientation in resource management.

\section{Discussion}

The results of this study identified three business model management typologies; comprehensive, risk and resource, which all are based on interplay between three groups of business model factors; i.e. 1) Key structural characteristics, 2) Key operational orchestration/activities and 3) Key dominate governance scheme, see Table 2.

Firstly, typical business models in the comprehensive demanding typology are identified as complex internet services with complex distribution channels and revenue models. On the contrary, business models in the simple typology are identified as simple mobile applications distributed through mobile service platforms with highly standardized distribution channels and revenue models. Secondly, typical business models in the high risk typology are identified as IT-services based on pre-determined payment but unclear work load input or own product development. In contrast, business models in the low risk typology are identified as IT consulting and customer tailored services. Thirdly, business models in the externally oriented resource typology are identified as complex media-music products and acting proactive in resource acquisition. On the contrary, typical business models in the internally oriented resource typology are identified as service production based on customer assignment, e.g. subscriptions service, and acting unreceptive in resource acquisition.

Table 2. The three business model management typologies ( $\mathrm{H}=\mathrm{High} ; \mathrm{L}=\mathrm{Low})$

\begin{tabular}{|c|c|c|c|}
\hline & Key structural characteristics & $\begin{array}{l}\text { Key operational orchestration/ } \\
\text { activities }\end{array}$ & Key dominate governance scheme \\
\hline Comprehen-sive: & H. uncertainty & H. information use & Stability in organizational structure \\
\hline Demanding & $\begin{array}{l}\text { H. complexity } \\
\text { H. variation }\end{array}$ & Complex decision process & Flexibility in business model design \\
\hline Comprehen-sive: & L. uncertainty & L. information use & Flexibility in organizational structure \\
\hline Simple & $\begin{array}{l}\text { L. complexity } \\
\text { L. variation }\end{array}$ & Simple decision process & Stability in business model design \\
\hline Risk: High & $\begin{array}{l}\text { H. business risk } \\
\text { H. social risk } \\
\text { H. financial risk }\end{array}$ & $\begin{array}{l}\text { Simple } \\
\text { L. information use } \\
\text { L. social network use }\end{array}$ & $\begin{array}{l}\text { Flexibility in organizational structure } \\
\text { Stability in business model design }\end{array}$ \\
\hline Risk: Low & $\begin{array}{l}\text { L. business risk } \\
\text { L. social risk } \\
\text { L. financial risk }\end{array}$ & $\begin{array}{l}\text { Extended } \\
\text { H. information use } \\
- \text { H. social network use }\end{array}$ & $\begin{array}{l}\text { Stability in organizational structure } \\
\text { Flexibility in business model design }\end{array}$ \\
\hline $\begin{array}{l}\text { Externally oriented } \\
\text { resource acquisition }\end{array}$ & $\begin{array}{l}\text { Dynamic technology environment } \\
\text { with } \mathrm{H} \text {. market focus } \\
\text { H. resource and resource } \\
\text { acquisition focus }\end{array}$ & $\begin{array}{l}\text { Extended use of resources and a } \\
\text { high degree of resource acquisition } \\
\text { activities } \\
\text { H. human capital } \\
\text { H. social capital } \\
\text { H. financial capital }\end{array}$ & $\begin{array}{l}\text { Flexibility in business model } \\
\text { organization and design regarding } \\
\text { resources and resource acquisition } \\
\text { activities. }\end{array}$ \\
\hline $\begin{array}{l}\text { Internally oriented } \\
\text { resource acquisition }\end{array}$ & $\begin{array}{l}\text { Stable technology environment } \\
\text { with low market focus } \\
\text { L. resource and resource } \\
\text { acquisition focus }\end{array}$ & $\begin{array}{l}\text { Limited use of resources and } \\
\text { resource acquisition activities } \\
\text { L. human capital } \\
\text { L. social capital } \\
\text { L. financial capital }\end{array}$ & $\begin{array}{l}\text { Stability in business model } \\
\text { organization and design regarding } \\
\text { resources and resource acquisition } \\
\text { activities. }\end{array}$ \\
\hline
\end{tabular}


The key structural characteristics for the first two management typologies belonging to the comprehensive dimension are characterized with high or low uncertainty, complexity, and variation in the business models management. The key operational activities should have a focus on management of information asymmetry in terms of uncertainty, complexity and variation and management of complex/simple decision processes. Hence, the key dominate governance should focusing on having a flexible or stable organizational structure and business model design.

The key structural characteristics for the two management typologies belonging to the risk dimension are characterized by a need to manage resource asymmetry in terms of human, social and financial resource and thus a setting of efficiency. The key operational activities should, depending on the degree of the business model risk, have a focus on management of the extent of information that need to be used and how to use different social networks. Hence, the key dominate governance should focusing on having a flexible or stable organizational structure and business model design. It is also interesting to note that high risk management strategies unexpectedly is connected to a low degree of information use while the low risk strategies are connected to a high degree of information use. This may be explained by that the low risk type of strategy typically refer to consultant businesses in the mobile service sector. Consultants also typically base their business on information and knowledge. High risk strategies may also imply a lack in relevant information that also explains the low use of information. It is here interesting to note that the comprehensive/demanding strategy is connected to stability in organizational structure and flexibility in business model design while the high risk strategy is connected to flexibility in organizational structure and stability in business model design.

The key structural characteristics for the resource management typology are characterized with the use of technology and resources. This leads to that the key operational activities should have a focus on how to use the resources and how to acquire them. That is, the resource management type of typology focuses on resources and resource acquisition where the proactive resource acquisition type (unreceptive) of strategy is connected to extended (limited) use of different types of resources and high (low) degrees of resource acquisition activities. The proactive type of strategy is characterized by the control mechanisms of flexibility in business model organization and flexibility in business model design regarding the resources and resource acquisition activities.

\section{Conclusion}

Business model development has become an important issue; perhaps even more so in relatively new and rapidly evolving sectors such as the mobile services industry (cf. Pigneur, 2002). Also as Chung et al. (2004) emphasize, the success of business models depends on the ability to adjust the business model in accordance to critical contextual factors. Therefore, this paper contributes to highlighting some of the contextual factors that should be managed depending on type of business model. The progress of the research on business model development is now entering into a fourth phase, focusing on business model management typologies and attached decision and control mechanisms. Findings from this study underscore a need of understanding the critical links between core characteristics and the mechanisms of decision and control related to three identified business model management strategies, i.e. 1) Comprehensive business model management strategy, focusing uncertainty, complexity, and variation in activities; 2) Risk business model management strategy, focusing on managing business, social, and financial risks; 3) Resource business model management strategy, focusing on managing external and internal resources. Each business model management typology gives direction for the control mechanisms providing flexibility or stability into the business model design and the business model organization.

This paper contributes also to a theoretical advancement in the field of business model development through the conceptualization of business model management typologies and attached underlying logics by 1) empirically identifying key factors behind business models, 2) identifying three core business model management strategies (six typologies), 3) identification of three cornerstones of characteristics and mechanisms related to the three business model management strategies, i.e. the key structural characteristics, key operational orchestration/activities and key dominate governance scheme, and 4) a conceptual framework depicting the six different business model management typologies and their characteristics.

Regarding the use of results, entrepreneurs and other interested in business model development can see a framework of the factors behind their business models, not just a set of statistics, but also the set of governance mechanisms and operational activities needed in the management of the business models. The framework also highlights what type of organizational structure and business model design that are required to support the business model management. Also, the framework can be used and benefit when feeding back results to practitioners who are less than wholly conversant with concepts of means or, more particularly, standard 
deviation and significance. Further, a cognitive mapping of entrepreneurs' business models displays entrepreneurs' own thinking about their business models, not in terms of someone else's idealized notion of the characteristics of business models. As such, not only does it avoid observer bias, but it is likely to generate greater interest in the results, in the sense that the entrepreneurs own the results. Thus as a consequence of the above, the cognitive maps can be used for training and business model development purposes. In addition to viewing the overall picture, entrepreneurs can evaluate both the own business models but also relate the own business models to business models experienced by other entrepreneurs (Senior, 1997).

In a dynamic industry, as the mobile service industry, companies need to rapidly develop and manage a range of different types of business models. Therefore, there is a need to have means to rapidly grasp what type of management is suitable for a specific business model and the characteristics of the management type. A tool box, guiding which activities and mechanisms are suitable for what business model, could rapidly support business model development with an understanding of how to manage information and decisions, what type of organisational structure is needed, what type of business model design, and the degree of stability and flexibility.

\section{References}

Amit, R., \& Zott, C. (2001). Value creation in e-business. Strategic Management Journal, 22, 493-520. http://dx.doi.org/10.1002/smj.187

Audretsch, D. B., \& Keilbach, M. (2008). Resolving the knowledge paradox: Knowledge-spillover entrepreneurship and economic growth. Research Policy, 37(10), 1697-1705. http://dx.doi.org/10.1016/j.respol.2008.08.008

Balachandra, R., \& Friar, J. H. (1997). Factors for success in R\&D projects and new product innovation: A conceptual framework. IEEE Transactions on Engineering Management, 44(3), 276-287. http://dx.doi.org/10.1109/17.618169

Ballon, P. (2007). Business modelling revisited: the configuration of control and value. Info, 9(5), 6-19. http://dx.doi.org/10.1108/14636690710816417

Bannister, D., \& Fransella, F. (2003). Inquiring man: The theory of personal constructs (3rd ed.).

Baum, J. R., Bird, B. J., \& Singh, S. (2011). The practical intelligence of entrepreneurs: Antecedents and a link with new venture growth. Personnel Psychology, 64(2), 397-425. http://dx.doi.org/10.1111/j.1744-6570.2011.01214.x

Brown, S. (1992). Cognitive mapping and repertory grids for qualitative survey research: Some comparative observations. Journal of Management Studies, 29(3). http://dx.doi.org/10.1111/j.1467-6486.1992.tb00666.x

Casadesus-Masanell, R., \& Ricart, J. E. (2010). From strategy to business models and onto tactics. Long Range Planning, 43, 195-215. http://dx.doi.org/10.1002/smj.2022

Cavalcante, S., Kesting, P., \& Ulhøi, J. (2011). Business model dynamics and innovation: (re)establishing the missing linkages. Management Decision, 49(8), 1327-1342. http://dx.doi.org/10.1108/00251741111163142

Chesbrough, H. (2007). Business model innovation: It's not just about technology anymore. Strategy \& Leadership, 35(6), 12-17. http://dx.doi.org/10.1108/10878570710833714

Chesbrough, H. (2010). Business model innovation: opportunities and barriers. Long Range Planning, 43(2), 354-363. http://dx.doi.org/10.1016/j.lrp.2009.07.010

Chesbrough, H., \& Rosenbloom, R. S. (2002). The role of the business model in capturing value from innovation: Evidence from Xerox Corporation's technology spin-off companies. Industrial and Corporate Change, 11(3), 529-555. http://dx.doi.org/10.1093/icc/11.3.529

Chesbrough, H., \& Schwartz, K. (2007). Innovating business models with co-development partnerships. Research Technology Management, 50(1), 55-59.

Chesbrough, H. W., \& Appleyard, M. M. (2007). Open innovation and strategy. California Management Review, 50(1), 57-76.

Chung, W. W. C., Yam, A. Y. K., \& Chan, M. F. S., (2004). Networked enterprise: A new business model for global sourcing. International Journal of Production Economics, 87, 267-280. http://dx.doi.org/10.1016/S0925-5273(03)00222-6

Demil, B., \& Lecocq, X. (2010). Business model evolution: In search of dynamic consistency. Long Range Planning, 43, 227-246. http://dx.doi.org/10.1016/j.lrp.2010.02.004 
Di Benedetto, C. A. (1996). Identifying the key success factors in new product launch. Journal of Product Innovation Management, 16, 530-544. http://dx.doi.org/10.1111/1540-5885.1660530

Diáz de Leon, E. D., \& Guild, P. (2003). Using repertory grid to identify intangibles in business plans. Venture Capital: An International Journal of Entrepreneurial Finance, 5(2), 135-160. http://dx.doi.org/10.1080/1369106032000097030

Dunn, W. N., \& Ginsberg, A. (1986). A sociocognitive network approach to organizational analysis. Human Relations, 39(11), 955-975. http://dx.doi.org/10.1177/001872678603901101

Eisenhardt, K. M. (1989). Agency theory: An assessment and review. Academy of Management Review, 14(1), 57-74. http://dx.doi.org/10.5465/AMR.1989.4279003

Fiske, S. T., \& Taylor, S. E. (1984). Social cognition. Reading, MA: Addison-Wesley.

Fransella, F., \& Bannister, D. (1977). A manual for repertory grid technique. London: Academic Press.

Fransella, F., \& Bell, R. (2003). Handbook of Personal Construct Psychology.

Fransella, F., Bell, R., \& Bannister, D. (2004). A manual for repertory grid technique (2nd ed.). Chichester: John Wiley \& Sons.

Gaines, B. R., \& Shaw, M. L. G. (1990). RepGrid 2 Manual. Calgary (Centre for Person Computer Studies).

Gary, M. S., \& Wood, R. E. (2011). Mental models, decision rules, and performance heterogeneity. Strategic Management Journal, 32(6), 569-594. http://dx.doi.org/10.1002/smj.899

Ginsberg, A. (1989). Constructing the business portfolio: A cognitive model of diversification. Journal of Management Studies, 26(4), 417-438. http://dx.doi.org/10.1111/j.1467-6486.1989.tb00737.x

Guest, G., Bunce, A., \& Johnson, L. (2006). How many interviews are enough? An experiment with data saturation and variability. Field Methods, 18(1), 59-82.

Hart, A. (1986). Knowledge acquisition for expert systems. London: Kogan Page.

Hippel, E. (2001). User toolkits for innovation. Journal of Product Innovation Management, 18(4), 247-257. http://dx.doi.org/10.1111/1540-5885.1840247

Hisrich, R. D., \& Jankowicz, D. (1990). Intuition in venture capital decisions: An exploratory study using a new technique. Journal of Business Venturing, 5(1), 49-62. http://dx.doi.org/10.1016/0883-9026(90)90026-P

Jankowicz, D. (2001). Why does subjectivity make us nervous? Making the tacit explicit. Journal of Intellectual Capital, 2, 61-73. http://dx.doi.org/10.1108/14691930110380509

Jankowicz, D. (2004). The Easy Guide to Repertory Grids. Wiley, Chichester, UK.

Johansson, J. (2004). Recommendation changes in walls of glass: perceived roles and relative importance of direct contacts. Luleå: Doctoral thesis / Luleå University of Technology; Nr 2004:52.

Johansson, J. M., \& Malmström, M. (2013). The business model transparency paradox in innovative growth ventures: Trade-offs between competitive advantages and agency costs. Entrepreneurship Research Journal, 3(2), 238-263. http://dx.doi.org/10.1515/erj-2012-0011

Johansson, J., \& Malmström, M. (2014). Financial Analysts as Makers or Breakers in the Financial Market. In G. Cunningham (Ed.), Reclaiming Accounting's Lost Identify. Mjölby: Atremi.

Johansson, J., Malmström, M., Chroneer, D., Styven, M. E., Engström, A., \& Bergvall-Kåreborn, B. (2012). Business models at work in the mobile service sector. Ibusiness, 4, 84 . http://dx.doi.org/10.4236/ib.2012.41010

Kelly, G. (1955). The Psychology of Personal Constructs. New York: Norton.

Kwong, C., Jones-Evans, D., \& Thompson, P. (2012). Differences in perceptions of access to finance between potential male and female entrepreneurs: Evidence from the UK. International Journal of Entrepreneurial Behaviour \& Research, 18(1), 75-97. http://dx.doi.org/10.1108/13552551211201385

Lindgren, P. (2012). Business model innovation leadership: How do SME's strategically lead business model innovation? International Journal of Business and Management, 7(14), 53. http://dx.doi.org/10.5539/ijbm.v7n14p53

Malmström, M. (2014). Typologies of bootstrap financing behavior in small ventures. Venture Capital, 16(1), 27-50. http://dx.doi.org/10.1080/13691066.2013.863064 
Malmström, M., \& Wincent, J. (2012). Modeling competence acquisition in small firms. International Journal of $\begin{array}{llll}\text { Entrepreneurship and Innovation } & \text { Management, } & \text { 15(1), }\end{array}$ http://dx.doi.org/10.1504/IJEIM.2012.044072

Malmström, M., Johansson, J., \& Wincent, J. (2014). Cognitive constructions of low - profit and high - profit business models: A repertory grid study of serial entrepreneurs. Entrepreneurship Theory and Practice. http://dx.doi.org/10.1111/etap.12096

Malmström, M., Wincent, J., \& Johansson, J. (2013). Managing competence acquisition and financial performance: An empirical study of how small firms use competence acquisition strategies. Journal of $\begin{array}{lllll}\text { Engineering and Technology } & \text { 30(4), }\end{array}$ http://dx.doi.org/10.1016/j.jengtecman.2013.07.004

Morris, M., Schindehutte, M., \& Allen, J. (2005). The entrepreneur's business model: Toward a unified perspective. Journal of Business Research, 58(6), 726-735. http://dx.doi.org/10.1016/j.jbusres.2003.11.001

Mosakowski, E. (1997). Strategy making under causal ambiguity: Conceptual issues and empirical evidence. Organization Science, 8(4), 414-442. http://dx.doi.org/10.1287/orsc.8.4.414

Osterwalder A., \& Pigneur, Y. (2004). An ontology for e-business models. In W. Currie (Ed.), Value Creation from E-Business Models. Oxford: Butterworth-Heinermann.

Osterwalder, A., Pigneur, Y., \& Tucci, C. L. (2005). Clarifying business models: origins, present, and future of the concept. Communications of the Association for Information Systems, 16(1), 1-25. Retrieved from http://aisel.aisnet.org/cais/vol16/iss1/1

Pateli, A., \& Giaglis, G. (2003). A framework for understanding and analysing e-Business models. Proceedings of the 16th Bled Electronic Commerce Conference eTransformation Bled, Slovenia, June 9-11. http://dx.doi.org/10.1057/palgrave. ejis.3000513

Petrovic, O., Kittl, C., \& Teksten, R. D. (2001). Developing Business Models for eBusiness. International Conference on Electronic Commerce 2001, Vienna.

Pope, M. L., \& Keen, T. R. (1981). Personal Construct Psychology and Education. Academic Press: London and New York.

Rayment, T. (2000). Art teachers' views of national curriculum art: A repertory grid analysis. Educational Studies, $26(2)$.

Senior, B. (1997). Team performance: Using repertory grid technique to gain a view from the inside. Team Performance Management, 3(1), 33-39. http://dx.doi.org/10.1108/13527599710171264

Shafera, S. M., Smitha, H. J., \& Linderberg J. C. (2005). The power of business models. Business Horizons, 48, 199-207.

Shaw, M. L. G. (1980). On becoming a personal scientist. London: Academic Press.

Shaw, M. L. G., \& Gaines, B. R. (1987). KITTEN: Knowledge initiation and transfer tools for experts and novices. International Journal of Man-Machine Studies, 27(3), 251-280. http://dx.doi.org/10.1016/S0020-7373(87)80055-X

Shaw, M. L. G., \& Woodward, B. (1990). Mental models in the knowledge acquisition process. Knowledge Acquisition, 2(3), 179-206. http://dx.doi.org/10.1016/S1042-8143(05)80015-9

Slater, P. (1976). The measurement of intrapersonal space by grid technique (Vol. 1). Explorations of interpersonal space. London: John Wiley \& Sons.

Slater, P. (1977). The measurement of interpersonal space by grid technique (Vol. 2). Dimensions of interpersonal space. London: John Wiley \& Sons.

Smith, M., Busi, M., Ball, P., \& Van Der Meer, R. (2008). Factors influencing an organisation's ability to manage innovation: A structured literature review and conceptual model. International Journal of Innovation Management, 12(4), 655-676. http://dx.doi.org/10.1142/S1363919608002138

Stewart, D. W., \& Zhao, Q. (2000). Internet marketing, business models, and public policy. Journal of Public Policy \& Marketing, 19(2), 287-296. http://dx.doi.org/10.1509/jppm.19.2.287.17125

Teece, D. J. (2010). Business models, business strategy and innovation. Long Range Planning, 43, 172-194. http://dx.doi.org/10.1016/j.lrp.2009.07.003 
Tidd, J., \& Trewhella, M. J. (1997). Organizational and technological antecedents for knowledge acquisition and learning. $R \& D$ Management, 27(4), 359-375. http://dx.doi.org/10.1111/1467-9310.00071

Van Der Meer, H. (2007). Open innovation-the Dutch treat: Challenges in thinking in business models. $\begin{array}{llll}\text { Creativity and Innovation } & \text { 192-202. }\end{array}$ http://dx.doi.org/10.1111/j.1467-8691.2007.00433.x

Westhead, P., Ucbasaran, D., \& Wright, M. (2005). Experience and Cognition Do Novice, Serial and Portfolio Entrepreneurs Differ? International Small Business Journal, 23(1), 72-98. http://dx.doi.org/10.1177/0266242605049104

Wiklund, J., \& Shepherd, D. (2003). Knowledge-based resources, entrepreneurial orientation, and the performance of small and medium-sized businesses. Strategic Management Journal, 24(13), 1307-1314. http://dx.doi.org/10.1002/smj.360

Xavier, V. (2008). Innovation and competitive pressure. Journal of Industrial Economics, 56(3), 419-469. http://dx.doi.org/10.1111/j.1467-6451.2008.00356.x

Yeung, K. W., \& Watkins, D. (2000). Hong Kong student teachers' personal construction of teaching efficacy. Educational Psychology, 20(2), 213-235. http://dx.doi.org/10.1080/713663713

Zott, C., \& Amit, R. (2010), Business model design: An activity system perspective. Long Range Planning, 43, 216-226. http://dx.doi.org/10.1016/j.lrp.2009.07.004

Appendix 1. The constructs in the Repertory Grid

\begin{tabular}{|c|c|c|c|}
\hline No & Construct & Pole (Low 1) & Contrast (High 7) \\
\hline $\mathrm{C} 1$. & Technology complexity & Low technology complexity & High technology complexity \\
\hline $\mathrm{C} 2$. & Product complexity & Low product complexity & High product complexity \\
\hline C3. & Uncertainty: Product technology & $\begin{array}{l}\text { Low uncertainty product } \\
\text { technology }\end{array}$ & High uncertainty product technology \\
\hline C4. & Market maturity & Low maturity market & High maturity market \\
\hline C5. & Market dynamics & Low market dynamic & High market dynamic \\
\hline C6. & $\begin{array}{l}\text { Possibility to influence the revenue } \\
\text { model }\end{array}$ & Low pos to influence revenue & $\begin{array}{l}\text { High post to influence revenue } \\
\text { model }\end{array}$ \\
\hline C7. & Use of social network & Low use of social network & High use of social network \\
\hline $\mathrm{C} 8$. & Information use & Low use of information & High use of information \\
\hline C9. & Complexity in sale structure & Low complexity in same structure & High complexity in same structure \\
\hline C10. & $\begin{array}{l}\text { Customer involvement in business } \\
\text { model }\end{array}$ & $\begin{array}{l}\text { Low customer involvement in } \\
\text { business model }\end{array}$ & $\begin{array}{l}\text { High customer involvement in } \\
\text { business model }\end{array}$ \\
\hline C11. & Earning from a time perspective & Earnings today & Earnings tomorrow \\
\hline C12. & Flexibility in business model & Low flexibility in business model & High flexibility in business model \\
\hline C13. & $\begin{array}{l}\text { Length of market window for } \\
\text { products }\end{array}$ & $\begin{array}{l}\text { Short market window for } \\
\text { products }\end{array}$ & Long market window for products \\
\hline C14. & Use of external sale channels & Low use of external sale channels & High use of external sale channels \\
\hline C15. & Level of organisational structure & $\begin{array}{l}\text { Low level of organisational } \\
\text { structure }\end{array}$ & $\begin{array}{l}\text { High level of organisational } \\
\text { structure }\end{array}$ \\
\hline C16. & $\begin{array}{l}\text { Technology focus in the business } \\
\text { model }\end{array}$ & $\begin{array}{l}\text { Low technology focus in the } \\
\text { business mode } 1\end{array}$ & $\begin{array}{l}\text { High technology focus in the } \\
\text { business model }\end{array}$ \\
\hline $\mathrm{C} 17$. & Degree of market focus & Low degree of market focus & High degree of market focus \\
\hline C18. & Use of external competence & Low use of external competence & High use of external competence \\
\hline C19. & Distance in customer relations & $\begin{array}{l}\text { Long distance in customer } \\
\text { relations }\end{array}$ & Short distance in customer relations \\
\hline $\mathrm{C} 20$. & Complexity in decision process & $\begin{array}{l}\text { Low complexity in decision } \\
\text { process }\end{array}$ & High complexity in decision process \\
\hline $\mathrm{C} 21$ & Capital intensity in business model & $\begin{array}{l}\text { Low capital intensity in business } \\
\text { model }\end{array}$ & $\begin{array}{l}\text { High capital intensity in business } \\
\text { model }\end{array}$ \\
\hline $\mathrm{C} 22$. & Business risk & Low business risk & High business risk \\
\hline C23. & Internal front edge competence & $\begin{array}{l}\text { Low degree of front edge } \\
\text { competence }\end{array}$ & $\begin{array}{l}\text { High degree of front edge } \\
\text { competence }\end{array}$ \\
\hline
\end{tabular}




\begin{tabular}{llll}
\hline C24. & $\begin{array}{l}\text { Internally generated financial } \\
\text { means }\end{array}$ & $\begin{array}{l}\text { Low degree of internally } \\
\text { generated financial means degree of internally generated }\end{array}$ & $\begin{array}{l}\text { Highancial mean } \\
\text { C25. }\end{array}$ \\
Financial loans external & Low degree of external financial High degree of external financial \\
loans & Low degree of external venture High degree of external venture \\
C26. & External venture capital & capital & capital \\
C27. & Sensitivity to business cycle & Low sensitivity to business cycle & High sensitivity to business cycle \\
\hline
\end{tabular}

\section{Copyrights}

Copyright for this article is retained by the author(s), with first publication rights granted to the journal.

This is an open-access article distributed under the terms and conditions of the Creative Commons Attribution license (http://creativecommons.org/licenses/by/3.0/). 